\title{
Research
}

\section{Using Traditional Ecological Knowledge to Improve Holistic Fisheries Management: Transdisciplinary Modeling of a Lagoon Ecosystem of Southern Mexico}

\author{
Alejandro Espinoza-Tenorio $^{1,2}$, Matthias Wolff $^{1}$, Ileana Espejel $^{3}$ and $^{\text {Gabriela Montaño-Moctezuma }}{ }^{4}$
}

\begin{abstract}
We developed a transdisciplinary modeling approach for the Huave Lagoon System (HLS), Mexico. This lagoon was selected because it has been used sustainably in various complimentary ways by different ethnic groups since pre-Hispanic times. Over the last few years, however, the ecological impact of artisanal fisheries in the region has grown significantly, thus endangering the balance between society and nature. Because the Huaves and the Zapotecs are ancestral fishing cultures with a profound knowledge of ecosystem resources and local property rights, the aim of this study was to identify ecosystem-level management alternatives capable of diminishing fishing impacts to the HLS. We used a consensus-building process and applied the user's traditional ecological knowledge (TEK). Our counterintuitive results show that specific management strategies should be considered for each particular fishing seascape within the HLS while taking into account the differences among ecological structures and fishery dynamics. The insights from this research aid in defining holistic management policies and support spatial allocations of use rights in local fisheries.
\end{abstract}

Key Words: consensus-building process; ecosystem-level management alternatives; fishing seascape; loop analysis; pressurestate-response framework; traditional ecological knowledge; transdisciplinary modeling

\section{INTRODUCTION}

Fisheries have traditionally been managed using speciesspecific regulations for commercially important stocks and by protecting sites of biological, social, or economic interest. However, most fisheries have not achieved sustainability based solely on the use of these guidelines (Christensen and Pauly 1995, Botsford et al. 1997). Although species-specific planning has been limited by factors such as a lack of assessment of indirect effects and a poor understanding of socioeconomic processes (Ludwig et al. 1993, Wilson 2006, Beddington et al. 2007), scientists have recently sought to develop new holistic management approaches. These new methodologies are based on the assumption that information regarding ecosystem processes is relevant to solving problems related to the decline of fisheries and the degradation of whole ecosystems (Pikitch et al. 2004). Thus, a series of holistic methodologies have been designed to consider ecosystemscale aspects such as species interactions, human impacts, and functional diversity (e.g., Loiselle et al. 2000, Ortiz and Wolff 2002, Montaño-Moctezuma et al. 2007, Smith et al. 2007).

The paradigm-shift from species-specific management to holistic system management has important implications for the fisheries regimes of tropical developing countries. With most capital investment coming from foreign loans, these countries' massive fisheries have largely followed the management policies of developed nations such as commandcontrol measures and single-species management, which despite their enormous theoretical background (Bailey and Jentoft 1990, Munro 2011), have more frequently failed than succeeded (Nauen 2002). Mexico is an example where, despite the long-term use of single-species regulations, the commercial harvest of fisheries resources has decreased dramatically. Currently, most Mexican fish stocks are considered to be fully exploited (46.3\%), overexploited (28.6\%), or even collapsed (18.3\%; Arreguin-Sánchez and Arcos-Huitrón 2011). According to previous studies (OrtizLozano et al. 2005, Sáenz-Arroyo et al. 2005, EspinozaTenorio et al. 2011a), the limited success of these regulations is due to a lack of understanding of ecosystem processes, the unreliable and biased information used to assess stock and ecosystem performance, and the insufficient involvement of local communities in management, conservation, and enforcement of measures. These circumstances are more complex in coastal lagoon ecosystems, where the artisanal fisheries are regionally important for alleviating poverty and satisfying domestic consumption, but share space with other increasing economic activities such as aquaculture, agriculture, livestock, and human settlement (Rivera-Arriaga and Villalobos 2001). In addition, as opposed to the stabilized industrial fleet, the artisanal fishery is the most numerous and increasing fleet (102,807 small-scale registered boats), which makes up $90 \%$ of the approximately 250,000 domestic fishermen in Mexico (OECD 2005).

To overcome the limitations of its fisheries regime, the Mexican government has recently been promoting holistic fisheries management initiatives. In Mexico, ancestral fishing cultures, like those of the Cucapa and Seri peoples, are anchored in a profound knowledge of marine and coastal 
ecosystem resources and local property rights (Basurto 2005). Therefore, the current Mexican Fishery Law (DOF 2007) incorporates fisheries comanagement plans with a novel characteristic: the consideration of traditional knowledge and administration systems into the decision making process. Thus, through consensus-building processes, native people can play a key role in supporting the management of the coastal lagoon resources on which they have relied for centuries.

In this study, the Huave Lagoon System (HLS) was selected because it has been used sustainably since pre-Hispanic times by Huave and Zapotec ethnic groups. In the HLS, artisanal fishermen have historically competed for resources without destroying fish populations because the artisanal fisheries are rooted in a profound understanding of the ecosystem, and they operate using a traditional organizational system (EspinozaTenorio 2010). However, this balance between society and nature is in danger because of external forces affecting fisheries management. For example, the politically convenient top-down decisions by the federal authorities modified the lagoon condition in the 1960s, when governmental policies changed the land use into the lagoon's watershed from a traditional multicropping farming system to an intensive one that requires higher fertilizer schemes (Espinoza-Tenorio et al. 2011b), which has been demonstrated elsewhere to be noxious (Islam and Tanaka 2004). In addition, fishing pressure has grown uncontrollably over the last several years because of human population growth, inappropriate fisheries regulations for the social context, and the lack of complete scientific information (Serrano-Guzmán et al. 2007).

Therefore, there is a need to identify ecosystem-level comanagement alternatives capable of diminishing fishing impacts on the HLS by using a consensus-building process and by applying the traditional ecological knowledge (TEK) of the resource users. To test innovative alternatives oriented to fish population recovery, a transdisciplinary modeling approach (sensu Morse et al. 2007) was used, in which the team, in this case fishermen, scientists, women, aquaculture users, local politicians, jointly defined research questions and developed research designs that integrated theoretical knowledge and practical problem solving. The approach followed the methodological arrangement suggested by Espinoza-Tenorio et al. (2010) that is based on the use of four core analytical methods: TEK, a pressure-state-response (PSR) framework, qualitative ecosystem modeling (loop analysis), and the use of Geographic Information Systems (GIS).

\section{DEFINITIONS AND CONCEPTS}

Within a fisheries context, holistic management requires an understanding of the likely consequences of human actions on complex ecosystem processes. Because complex socialecological systems (Berkes et al. 2003) are shaped by crossscale interactions, nonlinear feedbacks, and uncertainty
(Gunderson and Holling 2002), holistic approaches should involve all relevant sectors of society and scientific disciplines that should then share and synthesize new information (Pikitch et al.2004). To overcome the conceptual and idiomatic barriers among disciplines involved in describing and explaining ecosystems, Morse et al. (2007) proposed three levels of integration: collaborative and parallel research that is usually guided by traditional disciplinary approaches (multidisciplinary), coordinated works that are mutually developed into paradigms from multiple disciplines (interdisciplinary), and combined and collective planning that transcends disciplinary boundaries (transdisciplinary). The definition of contextspecific problems with multiple stakeholder perspectives and of transdisciplinary approaches that combine participatory and conventional methods and democratize knowledge to enable diverse inputs, including those from local, informal experts, is essential to the understanding of complex ecosystems (Cundill et al. 2005).

Holistic management requires the sharing and synthesis of a large range of environmental and socioeconomic information, including traditional and local ecological knowledge (Christie et al. 2007). TEK is an information source concerning species, ecosystems, and practices that is held by ancestral cultures that interact with ecosystems for their benefit and livelihood on a daily basis, over long periods of time (Berkes et al. 2000). Such TEK can potentially inform scientific approaches to management, either as a source of baseline data to fill information gaps that cannot otherwise be addressed, or to provide alternative management approaches from which scientists and managers might learn (Schafer and Reis 2008, Rist et al. 2010). Moreover, fishermen with intimate ecological knowledge of local conditions are able to appreciate the problems associated with overexploitation and are likely to feel that the resource should be managed for sustained harvest rather than for short-term gain (Ostrom 2009). Thus, holistic approaches revalue the contribution of users with more keen and founded awareness, and these approaches are moving from expert advice to an extended peer community (Berkes et al. 2001).

\section{METHODS}

The HLS is a complex coastal ecosystem formed by five interconnected lagoons (Laguna Superior, Laguna Inferior, Mar Tileme, Laguna Oriental, and Laguna Occidental) surrounded by five municipalities (Fig. 1): three Huave communities, San Dionisio del Mar, Francisco del Mar, and San Mateo del Mar, and two Zapotecs communities, Juchitán de Zaragoza and Santa María Xadani. The 24,736 Huaves and 93,152 Zapotecs inhabitants of these municipalities are distributed in 21 and 56 towns, respectively (INEGI 2005). Because of its fisheries resources, the HLS has been historically exploited by ancestral and creative small-scale fisheries techniques such as wooden boats powered by wind (Millán 2003), rustic oars and fish traps (Brockmann 2004), 
Fig. 1. The ethnic influence and fishing ports around the Huave Lagoon System, Mexico.

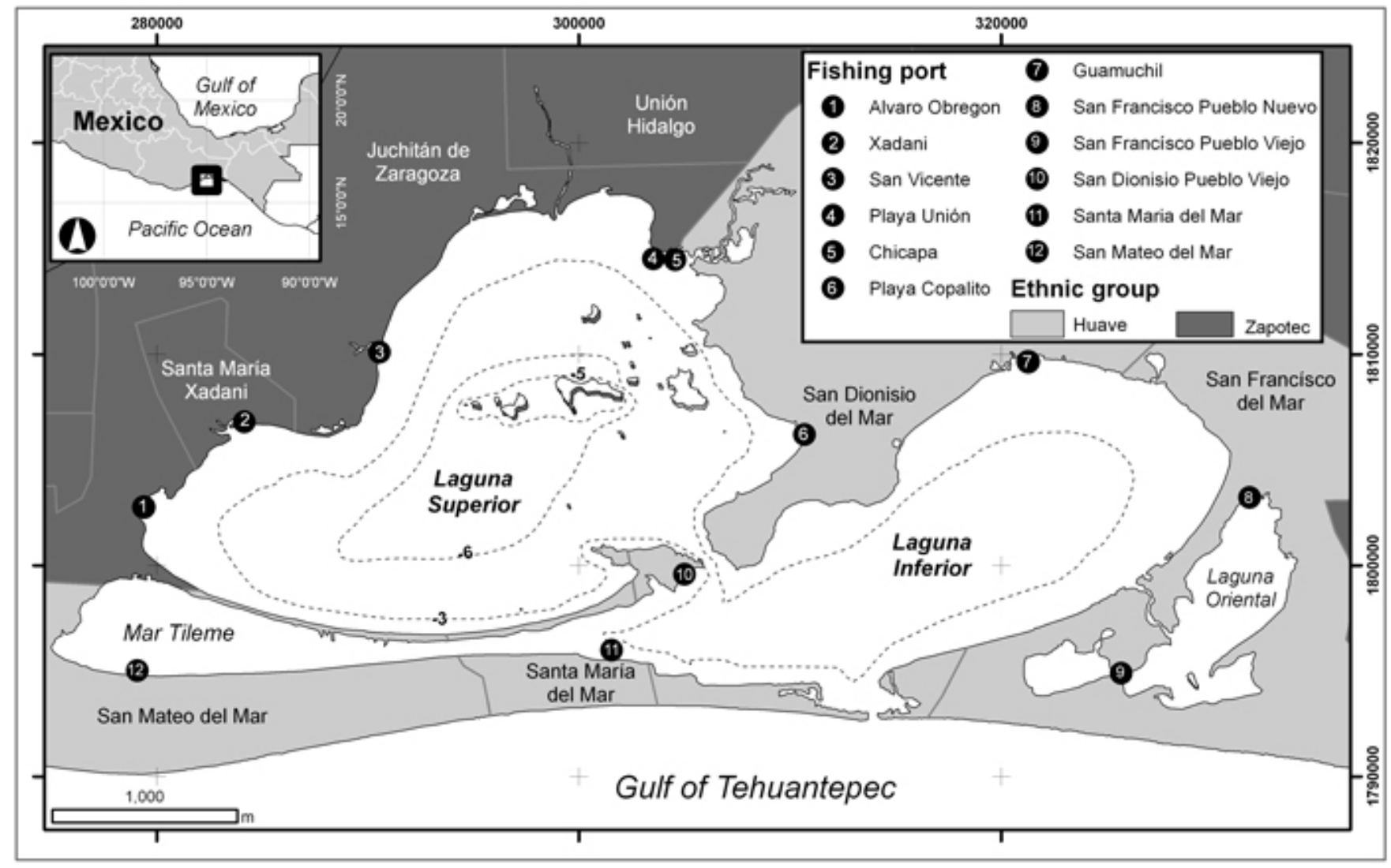

and a kite fishing system (Espinoza-Tenorio 2010). However, because of external political forces, environmental impacts, and the increasing fishing effort ( 8.9 fishermen $/ \mathrm{km}^{2}$; BozadaRobles 2008), the resources have severely declined and the ecosystems have been seriously modified (Serrano-Guzmán et al. 2007). Also, there are frequent ethnic conflicts caused by the property rights differences between Huaves and Zapotecs fishermen. These conflicts have impeded the access to the lagoon to authorities and academics, therefore the HLS is one of the least studied costal lagoons in Mexico (EspinozaTenorio et al. 2011b). In this sense, the opportunity that the interviewed fishermen gave to the team members was unique and very valuable.

To overlap the former limitations and build the transdisciplinary model, the team members used and combined, as a collective, core and complementary theoretical frameworks (TEK, PSR, and landscape ecology) and tools (environmental indicators, qualitative data collection techniques, loop analysis, and GIS) for the study of a complex lagoon ecosystem. In practical terms, the transdisciplinary approach followed five steps to the creation of new shared knowledge and areas of research (Fig. 2).
Quantitative and qualitative information was obtained regarding biological and social aspects of fisheries dynamics and management processes in the HLS. TEK was used to gather qualitative information that was difficult to obtain from the few technical reports from government fisheries. As is indicated in the Tables 1 and 2, (a) structured interviews with fishermen, (b) participatory research, (c) key informant interviews, and (d) workshops were conducted from January 2009 to March 2010 to involve the Huave (5) and Zapotec (7) fishing ports in the HLS in the construction and testing of the model.

For the structured interviews with fishermen, 33 interviewees (18 Zapotec and 15 Huave) were selected for their experience, as recognized by colleagues, from 10 official fishing cooperatives and three unregistered fishing groups (Table 1). They were local fishermen selected by asking cooperative leaders who were the most knowledgeable people regarding fisheries. The structured interviews (Appendix 1) consisted of 46 open and closed ended questions grouped in five sections: general data (7 questions; e.g., age, sex, birthplace), fishermen description (7 questions; e.g., years of practice, time fished per year, alternative economic activities), fisheries resources 
Table 1. Research strategy (structured interviews with fishermen) to collect the traditional ecological knowledge from Zapotec and Huave ethnics in the Huave Lagoon System, Mexico.

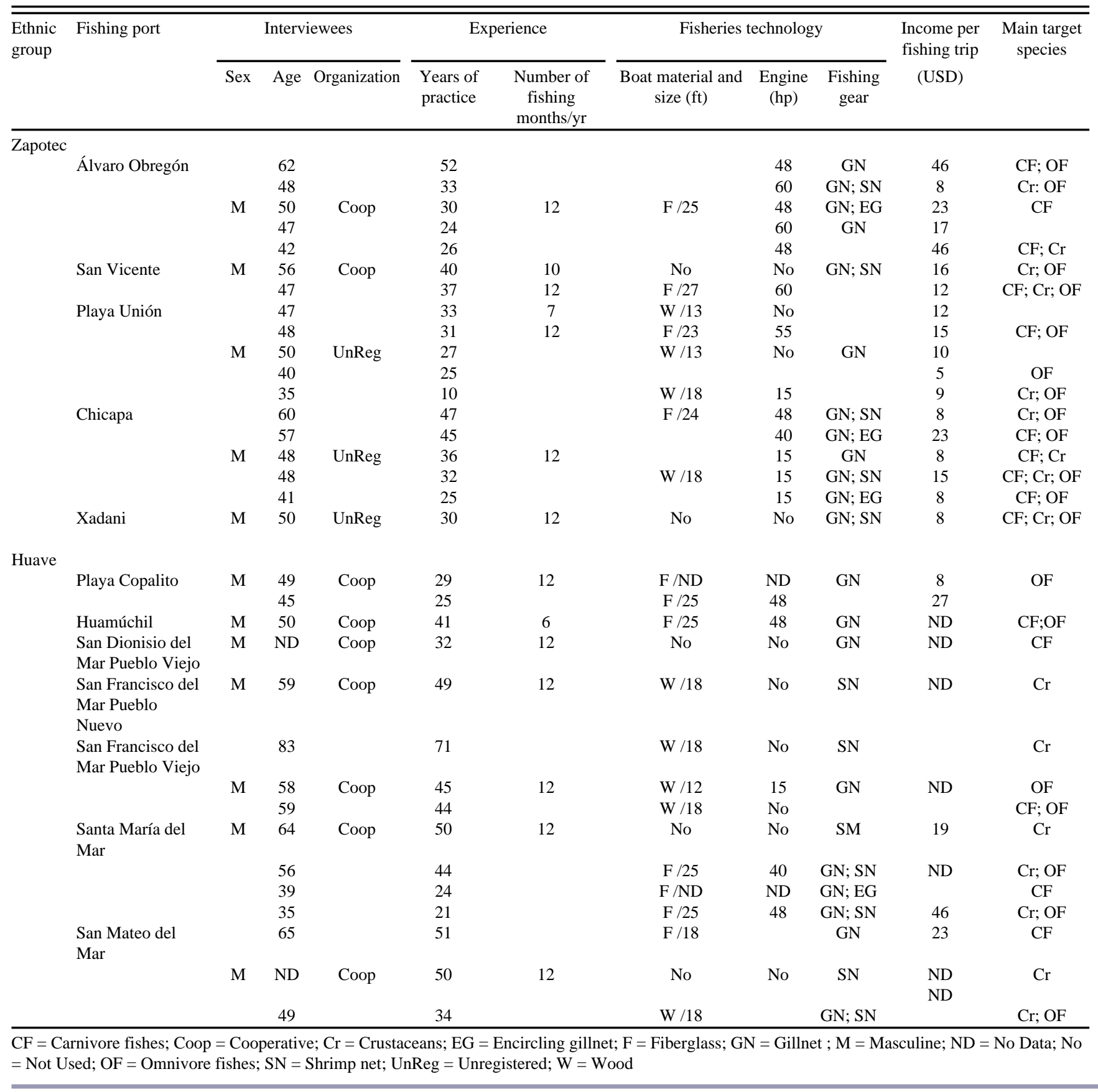

(20 questions; e.g., main target resources and fishing areas, fishing seasons, average size of the resources, trophic relationships, income per fishing trip), fisheries technology (4 questions; e.g., type of boat and fishing gear, assimilation of new technology), and natural resource management (8 questions; type of social organization, fisheries issues, conflict with others economic activities, endangered species). To elicit as much TEK as possible, questions on fisheries resources and fishing areas were asked about the three most abundant resources and the three productive areas. The use of predesigned maps of the HLS during the interviews allowed the fishermen to sketch their TEK regarding spatial variations in bathymetry, species distribution, main feeding areas, fishing seasons, and fishing gear. Given that fishers use common names for species, and most of the names differ among ethnic groups, we used fish local studies (e.g., Serrano-Guzmán 
Fig. 2. Flow diagram showing the assembly of the analysis tools that were utilized: (1) pressure-state-response, (2) loop analysis, and (3) Geographic Information System. The assemblage is subdivided into five steps (gray boxes): (a) indicator selection, (b) core model, (c) spatial analysis, (d) alternative models, and (e) model predictions (modified from EspinozaTenorio et al. 2010b).

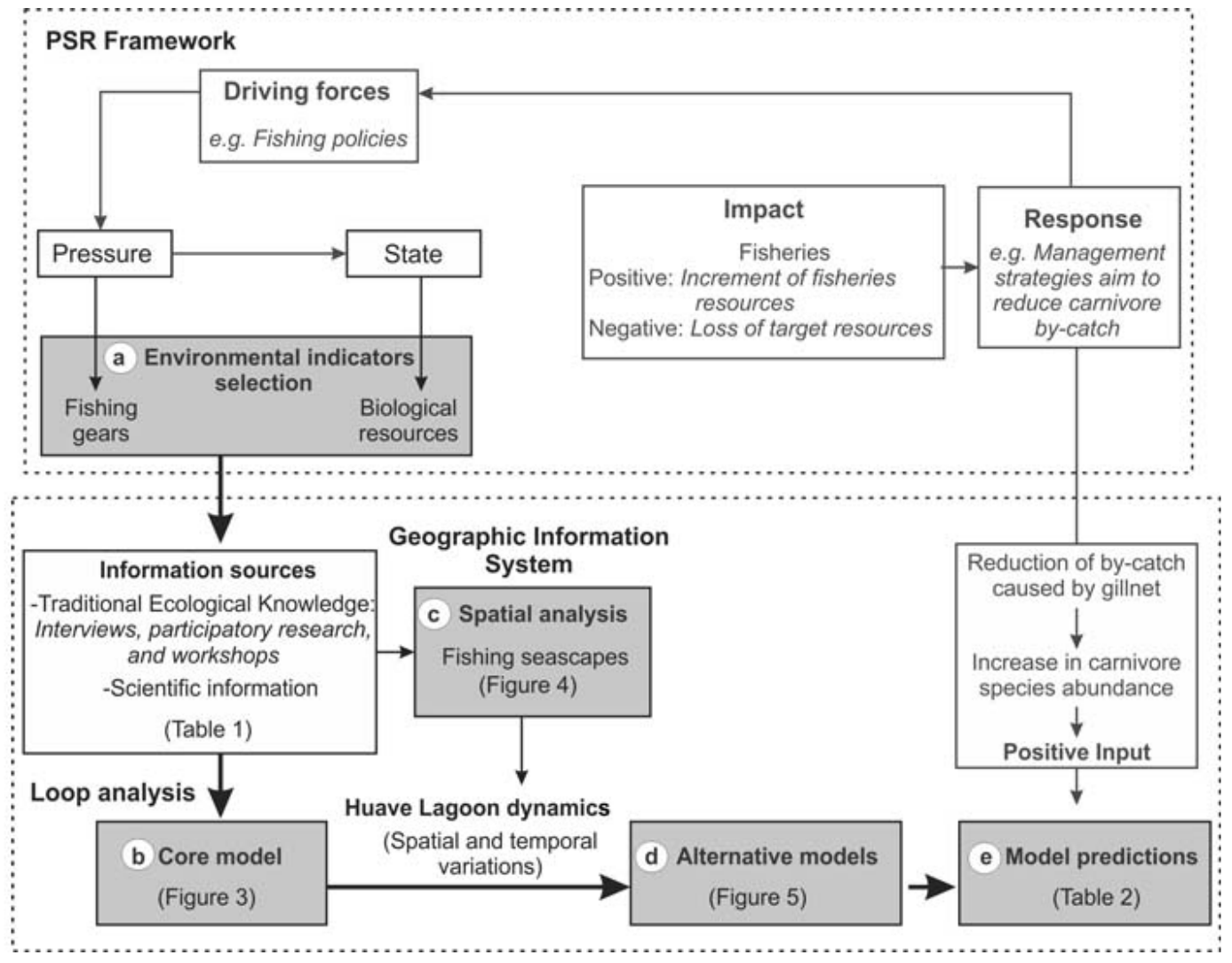

2004, Serrano-Guzmán et al. 2007) and photographs to clarify species identifications during the interviews. Responses to the questions were grouped into categories based on their content: description of the local fishermen, their knowledge about the fisheries resources and the lagoon, and the temporal and spatial variations of the fishery activity and ecological processes. For the last four categories, responses were formed by their frequency of occurrence and the most common were used in the construction of the model. For example, the main fishing areas were found by the overlap in a GIS (ESRI ${ }^{\circ}$ Arc MapTM 9.3.) of the zones most frequently used by the fishermen.

Further participatory research was conducted by living in the region for at least six months to understand the fishing system operating in the HLS. The first author spent this time in the community observing, listening, asking questions, and engaging in a variety of coastal activities, e.g., fisheries, aquaculture, agriculture, wind farms, artisan handicraft. In addition, the fieldwork team participated and became familiar with local fishing activities such as fishing and touristic trips, fishing gear, landings, and marketing. Throughout the research, the fieldwork team attended 24 meetings and 49 activities. Notes were taken and later discussed in key informant interviews and the workshops.

Thirty-nine key informants, i.e., aquaculture users, bilingual teachers, fishermen's wives, local politicians, and natural resources administrators, were systematically interviewed to elicit information on traditional worldview and practices, Huave-Zapotec-Spanish translations, and the current administrative system. The key informant interviews also examined information about the main fisheries issues such properties rights, marketing, and fishing bans.

Twelve workshops were organized in 2010 with the 30 leaders of the fishery cooperatives and the 15 oldest fishermen in each of the fishing ports to corroborate key information gathered during the structured interviews with fishermen, the participatory research, and key informant interviews, as well as to fill information gaps. In addition, we asked them to discuss an inclusive consensual spatial assignment of the fisheries and to suggest convenient consensual management 
Table 2. Research strategy (participatory research, key informant interviews, and workshops) to collect the Traditional Ecological Knowledge from Zapotec and Huave ethnics in the Huave Lagoon System, Mexico.

\begin{tabular}{|c|c|c|c|c|c|c|c|}
\hline \multirow{2}{*}{$\begin{array}{l}\text { Ethnic } \\
\text { group }\end{array}$} & \multirow[t]{2}{*}{ Fishing port } & \multicolumn{2}{|c|}{ Participatory research } & \multirow[t]{2}{*}{ Key informant interviews } & \multicolumn{3}{|c|}{ Workshops } \\
\hline & & Number of meetings & Number of activities & & Number & $\begin{array}{l}\text { Number of } \\
\text { participants }\end{array}$ & $\begin{array}{l}\text { Length } \\
\text { (h) }\end{array}$ \\
\hline \multicolumn{8}{|l|}{ Zapotec } \\
\hline & Álvaro Obregón & Cooperative (2) & $\begin{array}{l}\text { Marketing (2); fishing trip } \\
\text { (1); fish landing (1) }\end{array}$ & ND & 1 & 6 & 3 \\
\hline & San Vicente & Cooperative (2) & $\begin{array}{l}\text { Marketing (3); fish landing } \\
\text { (1) }\end{array}$ & $\begin{array}{l}\text { Local politicians (5); } \\
\text { fishermen's wives (2), } \\
\text { bilingual teachers (2); } \\
\text { natural resources } \\
\text { administrators (2) }\end{array}$ & 1 & 4 & 2 \\
\hline & Playa Unión & $\begin{array}{l}\text { Unregistered fishing } \\
\text { group (1) }\end{array}$ & Fish landing (2) & $\begin{array}{l}\text { Aquaculture users (1); local } \\
\text { politicians (1) }\end{array}$ & 1 & 5 & 2 \\
\hline & Chicapa & $\begin{array}{l}\text { Unregistered fishing } \\
\text { group (1) }\end{array}$ & $\begin{array}{l}\text { Marketing (1); fish landing } \\
\text { (1) }\end{array}$ & Aquaculture users (1) & 1 & 3 & 3 \\
\hline & Xadani & $\begin{array}{l}\text { Unregistered fishing } \\
\text { group (1) }\end{array}$ & $\begin{array}{c}\text { Marketing (2); fishing trips } \\
\text { (1) }\end{array}$ & Local politicians (2) & 1 & 5 & 4 \\
\hline & Subtotal & 7 & 15 & 16 & 5 & 23 & 14 \\
\hline \multicolumn{8}{|l|}{ Huave } \\
\hline & Playa Copalito & Cooperative (2); & $\begin{array}{l}\text { Fish landing (3); fishing trip } \\
\text { (1); marketing (1); touristic } \\
\text { trip (1) }\end{array}$ & $\begin{array}{l}\text { Bilingual teachers (2); local } \\
\text { politicians (2) }\end{array}$ & 1 & 4 & 3 \\
\hline & Huamúchil & Cooperative (2) & $\begin{array}{c}\text { Marketing (1); fish landing } \\
\text { (1) }\end{array}$ & ND & 1 & 3 & 4 \\
\hline & $\begin{array}{l}\text { San Dionisio del Mar } \\
\text { Pueblo Viejo }\end{array}$ & Communal (1) & $\begin{array}{l}\text { Marketing (1); } \\
\text { fish landing (1) }\end{array}$ & ND & 1 & 3 & 2 \\
\hline & $\begin{array}{l}\text { San Francisco del Mar } \\
\text { Pueblo Nuevo }\end{array}$ & Cooperative (1); & $\begin{array}{l}\text { Marketing (2); fish landing } \\
\text { (2); fishing trip (1) }\end{array}$ & $\begin{array}{l}\text { bilingual teachers (2); local } \\
\text { politicians (2) }\end{array}$ & 1 & 3 & 4 \\
\hline & $\begin{array}{l}\text { San Francisco del Mar } \\
\text { Pueblo Viejo }\end{array}$ & $\begin{array}{l}\text { Cooperative (2); } \\
\text { communal (2) }\end{array}$ & $\begin{array}{c}\text { Fish landing (3); marketing } \\
\text { (2) }\end{array}$ & $\begin{array}{l}\text { bilingual teachers (1); } \\
\text { aquaculture users (1); local } \\
\text { politicians (1) }\end{array}$ & 1 & 4 & 4 \\
\hline & Santa María del Mar & $\begin{array}{l}\text { Communal (3); } \\
\text { cooperative (2) }\end{array}$ & $\begin{array}{l}\text { Fishing trips (3); fish } \\
\text { landing (3); marketing (2); } \\
\text { touristic trip (1) }\end{array}$ & $\begin{array}{c}\text { Bilingual teachers (3); } \\
\text { fishermen's wives (2); local } \\
\text { politicians (2) }\end{array}$ & 1 & 5 & 4 \\
\hline & San Mateo del Mar & Cooperative (2) & $\begin{array}{l}\text { Marketing (3); } \\
\text { fish landing (2) }\end{array}$ & $\begin{array}{l}\text { Local politicians (3); } \\
\text { bilingual teachers (1); } \\
\text { natural resources } \\
\text { administrators (1) }\end{array}$ & 1 & 4 & 3 \\
\hline & Subtotal & 17 & 34 & 23 & 7 & 26 & 24 \\
\hline & TOTAL & 24 & 49 & 39 & 12 & 49 & 38 \\
\hline
\end{tabular}

ND = No Data

goals. These workshops were conducted in public or cooperative and communal spaces and their length was approximately 3 hours on average. Finally, TEK was validated using quantitative data from general scientific literature (Froese and Pauly 2011) and scientists from regional universities (e.g., Universidad del Mar) and research institutes (e.g., CRIP-Salina Cruz, Oaxaca) specializing in marine ecology, fisheries, and taxonomy.

\section{Environmental indicators}

The PSR framework proposed by the Organization for Economic Co-operation and Development (OECD 1993) was used to select and organize simple indicators that provide useful evidence about the ecosystem. The PSR framework was chosen because it is based on a concept of causality: human activities exert "pressure" on the environment and change its quality and the quantity of natural resources ("state"). Society "responds" to these changes through general economic, environmental, and sectorial policies. For this study, two types of indicators were used: those describing the "state" of fisheries resources and those describing the indirect fishing "pressure" on these resources (Fig. 2a). Societal response was not used as an indicator but as an agent of disturbance within 
the model. Indicators of the state of fishery resources were grouped according to species that have similar roles in the marine community and in the local artisanal fisheries, i.e., similar abundance, bycatch proportion, feeding habits, and importance as fishing resources (Table 3). Because information on the pressures directly exerted on all resources is lacking for the HLS, e.g., fish mortality and exploitation rate, indicators of indirect pressures were created based on fishing gear, and these were grouped by gear selectivity and intensity of usage recognized by the local fishers (EspinozaTenorio et al. 2011b). The use of these practical criteria in designing the fishery indicators represents fishing pressure in a way that can be managed and understood by local people and government stakeholders.

\section{Ecosystem modeling approach}

Loop analysis was used to represent the HLS ecosystem and analyze its response to a specific management strategy (Fig. $2 b)$. This technique denotes the main relationships between biological and fishery variables, i.e., between state and pressure indicators, and uses signed digraphs to represent a simple matrix of positive interactions $(\rightarrow)$, negative interactions (-•), and no interactions $(0)$ between model variables. Biologically, the positive effect of one variable on another translates to ecological benefits or improved conditions, e.g., increase in prey abundance or in availability of fishing resources. The opposite is true in the case of negative relationships, which represent negative effects on the variable, e.g., greater number of predators and fewer fishing resources. Self-regulating effects are represented as links that begin and end at the same variable. These denote processes that regulate the variables, e.g., population density-dependent factors, or additional predators not specifically included in the system.

The direction of change in the abundance of each variable after a disturbance is obtained from the inverse of the community matrix $\left(A^{-1}\right)$ or prediction matrix (Levins 1974), which predicts the response of a positive or negative disturbance on each community member. To overcome some of the most serious conceptual limitations of loop analysis (Justus 2006), models were tested for stability and "weighted" reliability in their predictions. A model is considered stable if, after a disturbance, variable levels increase or decrease but finally return to prior levels (Puccia and Levins 1985). Stability was tested considering two mathematical criteria based on the feedback characteristics of each model: (a) feedback at all levels should be negative and (b) negative feedback at high levels cannot be too strong, compared to lower levels (the Hurtwitz determinants should be $>0$; Puccia and Levins 1985). Weighted predictions incorporate the probability of a given prediction, so predictions $>0.4$ are considered to be reliable (Dambacher et al. 2002). PowerPlay Digraph Editor Version $2.0 ®$ and Maple Version $5.00 \AA$ were used to construct the signed digraphs and generate the model predictions.
The utility of loop analysis was described by Puccia and Levins (1985) using a simple system of three variables: nutrients (N), herbivores $(\mathrm{H})$, and predators (P; Fig. 3). The nutrients are used by the herbivore, which in turn is eaten by the predator. Herbivores and predators are self-regulated because each variable is connected to another stable system. A prediction matrix (Fig. 3c) shows how each variable abundance level will change, i.e., increase, decrease, or remain the same, because of modifications in the growth rate of one variable. For instance, if a positive disturbance causes an increase in predator abundance (highlighted column), herbivores will decrease because of higher rates of predation, and nutrients will increase because of less consumption by herbivores.

Fig. 3. a) Model signed-digraph, b) Community matrix, and c) Prediction matrix for a simple system of three variables: nutrients $(\mathrm{N})$, herbivores $(\mathrm{H})$, and predators $(\mathrm{P})$. Matrix elements (aij) were obtained from the signed-digraph and its negative $(-\bullet)$ and positive $(\rightarrow)$ links. The prediction matrix indicates a positive disturbance (black arrow) that affects predators and shows the response of each member of the community to this disturbance (highlighted column).

\section{a) Signed-digraph}

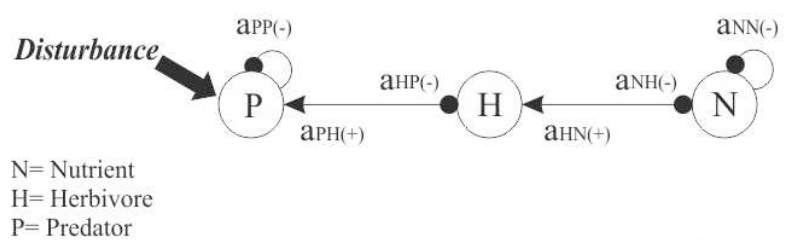

b) Community matrix

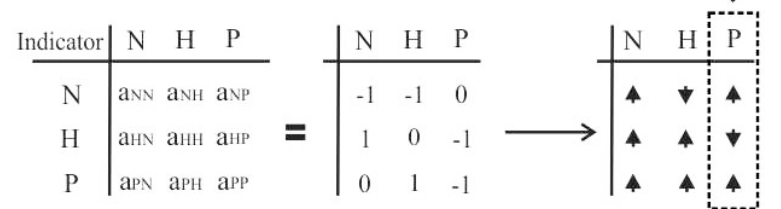

A core model was constructed for the HLS representing all possible interactions between ecosystem members (Fig. 4). To identify the most important relationships among groups, we used the species with higher percentages of occurrence in the stomach contents of different ecosystem members. Less frequent interactions were not included. For example, sea turtles (ST) can prey on mollusks (MBC), carnivore bycatch (CBC), carnivore fishes $(\mathrm{CF})$, and crustaceans $(\mathrm{Cr})$; however, mollusks (MBC) were identified by the fishermen as the most common prey in the stomach contents of the sea turtles in the HLS. Interactions among biological resources were mainly predator-prey relationships $(\leftarrow \bullet)$, but negative connections among biological resources and fishing gear can exist because of the effect of the gillnet bycatch on sea turtles $(\mathrm{GN}-\bullet \mathrm{ST})$. 
Table 3. Traditional ecological knowledge related to (A) biological (state) and (B) fishing (pressure) indicators selected for the Huave Lagoon System, Mexico. The seven biological indicators were grouped into bycatch and target species.

\begin{tabular}{|c|c|c|}
\hline (A) Biological indicator & Species & Main feeding habits \\
\hline \multicolumn{3}{|l|}{ Bycatch } \\
\hline Omnivore (OBC) & $\begin{array}{l}6 \text { species } \\
\text { - Sea catfish (1. Arius platypogon, 2. A. seemanii, 3. Cathorops fuerthii); } \\
\text { - Anchovy (4. Anchoa curta, 5. A. ischana, 6. Anchovia macrolepidota) }\end{array}$ & $\begin{array}{c}\text { Fish, polychaetae, algae, detritus, and } \\
\text { microalgae }\end{array}$ \\
\hline Carnivore (CBC) & $\begin{array}{l}24 \text { species } \dagger: \\
\text { - Grunt (1. Pomadasys panamensis); } \\
\text { - Short-snout mojarra (2. Diapterus peruvianus); } \\
\text { - Bonefish (3. Albula nemoptera, 4. A. vulpes); } \\
\text { - Flounder (5. Archirus mazatlanus, 6. A. zebrious); } \\
\text { - Golden jack (7. Gnathanodon speciosus), } \\
\text { - Leatherjack (8. Oligoplites saurus, 9. O. altus); } \\
\text { - Carruco grunt (10. Anisotremus pacifici); } \\
\text { - Milk fish (11. Chanos chanos); } \\
\text { - Croaker (12. Micropogonias altipinnis) }\end{array}$ & Fish, mollusks, and crustaceans \\
\hline Mollusks (MBC) & $\begin{array}{l}2 \text { species: } \\
\text { - Pacific crown conch (1. Melongena patula); } \\
\text { - Rocksnail (2. Hexaplex spp.) }\end{array}$ & $\begin{array}{l}\text { Filter feeders and carnivores (other } \\
\text { mollusk) }\end{array}$ \\
\hline Sea turtle (ST) & $\begin{array}{l}\text { - Olive ridley turtle (1. Lepidochelys olivacea); } \\
\text { - Pacific green turtle (2. Chelonia agassizi) }\end{array}$ & $\begin{array}{c}\text { Carnivores (crustaceans and mollusk) } \\
\text { and omnivores }\end{array}$ \\
\hline \multicolumn{3}{|l|}{ Target Species } \\
\hline Crustaceans $(\mathrm{Cr})$ & $\begin{array}{l}5 \text { species: } \\
\text { - Shrimps (1. Litopenaeus stylirostris, 2. L. vannamei); } \\
\text { - Crabs (3. Callinectes belicosus, 4. C. arcuatus, 5. C. toxotes) }\end{array}$ & $\begin{array}{c}\text { Filters feeders and carnivores (others } \\
\text { crustaceans) }\end{array}$ \\
\hline Carnivore fishes $(\mathrm{CF})$ & $\begin{array}{l}8 \text { species: } \\
\text { - Yellowfin snook (1. Centropomus robalito); } \\
\text { - Snapper (2. Lutjanus argentiventris,3. L. Colorado,4. L. novemfasciatus); } \\
\text { - Brown sea catfish (5. Sciades dowii); } \\
\text { - Corvina (6. Cynoscion reticulatus, } 7 \text {. C. stolzmanni, 8. C. phoxocephalus) }\end{array}$ & Carnivores (fish) \\
\hline Omnivore fishes (OF) & $\begin{array}{l}3 \text { species: } \\
\text { - Mullet (1. Mugil cephalus, 2. M. curema); } \\
\text { - Yellow fin mojarra (3. Gerres cinereus) }\end{array}$ & $\begin{array}{c}\text { Fish, polychaetae, algae, detritus, and } \\
\text { microalgae }\end{array}$ \\
\hline (B) Fishing indicator & Fishing gear (fleet) & Related resources \\
\hline Shrimp net (SN) & Cast nets and beach seines (on foot) & Crustaceans, omnivore bycatch \\
\hline Gillnets (GN) & Set gillnets (fiberglass boats and wood canoes) & $\begin{array}{l}\text { Carnivore and omnivore fishes, sea } \\
\text { turtles, carnivore bycatch }\end{array}$ \\
\hline Encircling gillnet (EG) & Purse seines (fiberglass boats) & Carnivore fishes \\
\hline
\end{tabular}

Self-regulation effects on biological resources (e.g., MBC - MBC) represented both cannibalism and density-dependent processes. Self-regulation effects on fishing gear (e.g., SN - $\mathrm{SN}$ ) included normative aspects that were not included as variables in the model, for example, the number of shrimp nets (SN) regulated by fishing authorities.

\section{Spatio-temporal variability}

To analyze HLS dynamics, alternative models were built considering the spatial and temporal variation in harvest regimes and the presence or absence of specific resources (Fig. 2c,d). A spatial classification system was used to construct these alternative models for different fishing seascapes based on the landscape ecology concept for aquatic environments (Hunsaker and Hughes 2002). We defined a fishing seascape as a region with a particular combination of fishery resources and human activities. In this way, the spatial variation of the fishing seascape was designed according to the TEK of the HLS. The area covered by each seascape was also calculated. This spatial analysis was conducted by the GIS.

Seasonal changes in resource availability within a seascape were identified as changes in fishery target species that align with changes in fishing gears. Three fishing seasons were identified: (1) shrimp, May to July; (2) low fishing season, October to February; and (3) fishes, March to April and August 
Fig. 4. a) Core model signed-digraph, b) Community matrix, and c) Prediction matrix for the Huave Lagoon System, Mexico. Matrix elements (aij) were obtained from the signed-digraph. Example: The interaction between sea turtles and mollusk bycatch is depicted by the matrix elements a27 (-) and a72 (+), which correspond to a negative $(-\bullet)$ and positive $(\rightarrow)$ link, respectively. All self-effects are shown in the matrix diagonal, indicated as a11, a22, a33, etc. The prediction matrix indicates a positive disturbance (black arrow) that causes an increase in carnivorous bycatch species (CBC), and shows the response of each member of the community to this disturbance (marked column). The indicators and their relationships were constructed from Table 1.

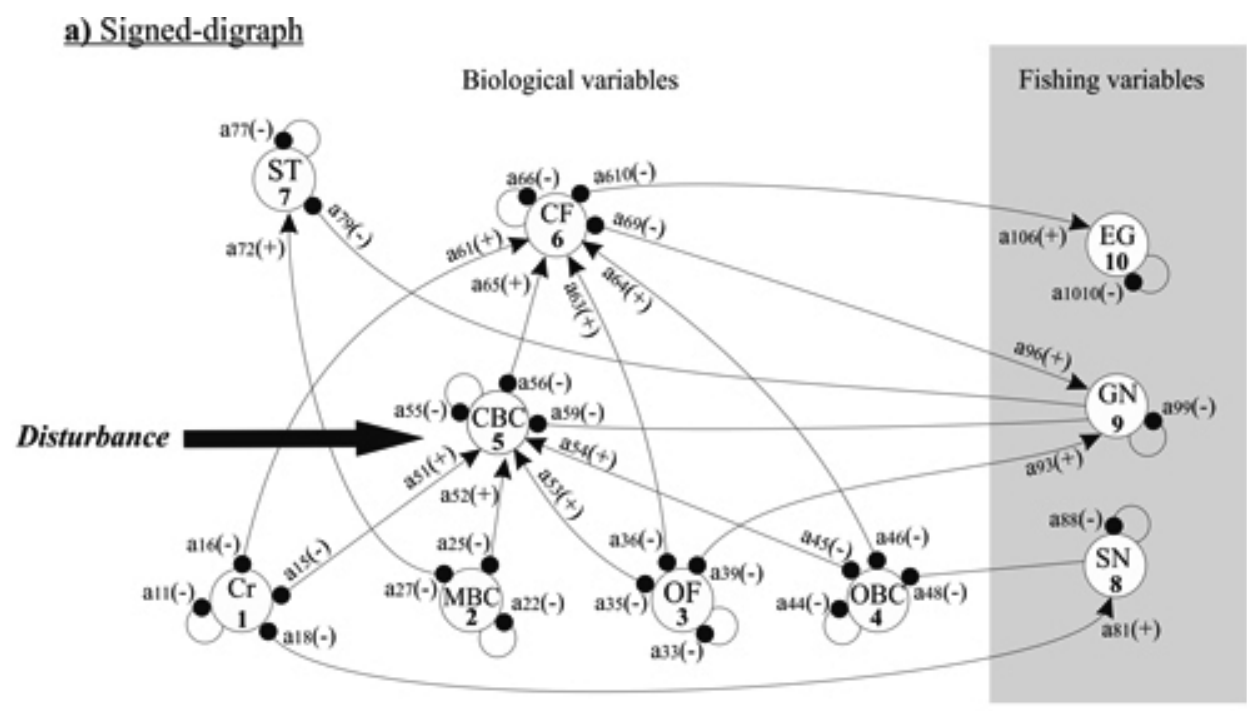

\author{
Biological indicators \\ $\mathrm{CBC}=$ Carnivore By-Catch \\ $\mathrm{CF}=$ Camivore Fishes \\ $\mathrm{Cr}=$ Crustaceans \\ $\mathrm{MBC}=$ Mollusks By-Catch \\ $\mathrm{OBC}=\mathrm{Omnivore} \mathrm{By}-\mathrm{Catch}$ \\ OF= Omnivore Fishes \\ $\mathrm{ST}=\mathrm{Sea}$ Turtle \\ Fishing indicators \\ $\mathbf{E G}=$ Encireling gillnet \\ $\mathrm{GN}=$ Gillnet \\ $\mathrm{SN}=$ Shrimp net
}

b) Community matrix

\begin{tabular}{|c|c|c|c|c|c|c|c|c|c|c|}
\hline \multirow[b]{2}{*}{ Indicator } & \multicolumn{6}{|c|}{ Bielogical variables } & \multicolumn{4}{|c|}{ Fishing variables } \\
\hline & $\begin{array}{c}1 \\
\mathrm{Cr} N\end{array}$ & $\stackrel{2}{\mathrm{MBC}}$ & $\stackrel{3}{O F}$ & $\stackrel{4}{\mathrm{OBC}}$ & $\begin{array}{c}5 \\
\mathrm{CBC}\end{array}$ & $\stackrel{6}{C F}$ & $\begin{array}{c}7 \\
\text { ST }\end{array}$ & $\begin{array}{c}8 \\
\text { SN }\end{array}$ & $\stackrel{9}{\mathrm{GN}}$ & $\begin{array}{c}10 \\
\text { EG }\end{array}$ \\
\hline $\mathrm{Cr}$ & an & a12 & a13 & al4 & als & a16 & a17 & a18 & a19 & allo \\
\hline $\mathrm{MBC}$ & a21 & an2 & a23 & a24 & a2s & a2s & a27 & a2s & asy & a210 \\
\hline OF & a31 & a32 & $\mathbf{a 3 3}$ & a34 & ass & a36 & a37 & ass & a39 & a310 \\
\hline $\mathrm{OBC}$ & as! & a42 & a43 & ast & a45 & a+to & a47 & a4s & aw & a410 \\
\hline $\mathrm{CBC}$ & as1 & as2 & ass & as4 & ass & as6 & ast & ass & as9 & as 10 \\
\hline $\mathrm{CF}$ & a61 & $a 62$ & a63 & ast & abs & ab6 & a67 & a6s & a69 & a610 \\
\hline ST & an & anz & an & a7s & a7s & a) & an & a7s & axy & a710 \\
\hline $\mathrm{SN}$ & asi & $a \times 2$ & ax3 & as4 & ass & ass & as7 & ass & ass & as10 \\
\hline GN & a91 & a92 & a93 & as & a95 & 296 & a97 & a9s & a99 & a910 \\
\hline EG & atol & $a_{1} c_{2}$ & a 103 & a104 & atos & a 106 & a 107 & 7 a 108 & a 109 & a1010 \\
\hline
\end{tabular}

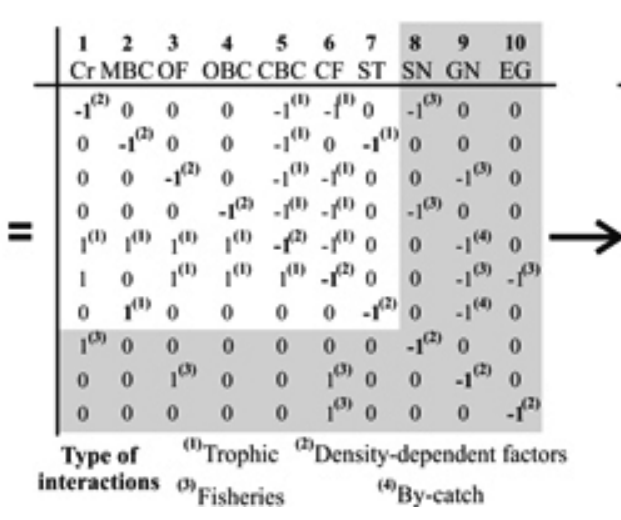

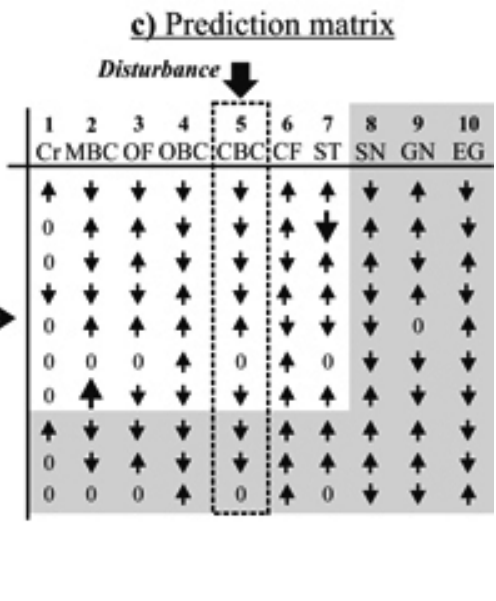

to September. By analyzing the fisheries resource availability over the year, it was possible to determine temporal changes in target species or groups that apply for each seascape.

\section{Disturbance}

According to the PSR framework, a positive disturbance in the ecosystem model corresponds to a societal response that successfully mitigates human-induced negative impacts on the environment. In the HLS, fisheries have been a subsistence activity for centuries, but fish numbers have recently shown a tendency to decrease and the local survival tactic has been to increase bycatch extraction rate, resources that were not used previously (Espinoza-Tenorio et al. 2011b). However, most of these species are secondary carnivores (see Table 3) and therefore are located in a key place for the energy flow through the trophic net (Espinoza-Tenorio et al. 2010). Therefore, the fish population recovery in the HLS is crucial to alleviate local poverty and to recover previous ecological processes of the ecosystem, thus, recovering its resilience or its capacity to absorb disturbances while maintaining function (Berkes et al. 2003). The ecosystem response was analyzed when strategies such as bycatch reduction, suggested for the most popular fishing gear (gillnet fishery), were enforced. For 
Fig. 5. Huave Lagoon System regionalization according to seasonal variations of fisheries resources. The percentage cover of each fishing seascape was: shallow lagoon $=39.3 \%$, lagoon $=38.4 \%$, islands and channel $=10.4 \%$, shoreline $=7.7 \%$, wetlands $=3.6 \%$, mouth $=0.6 \%$.

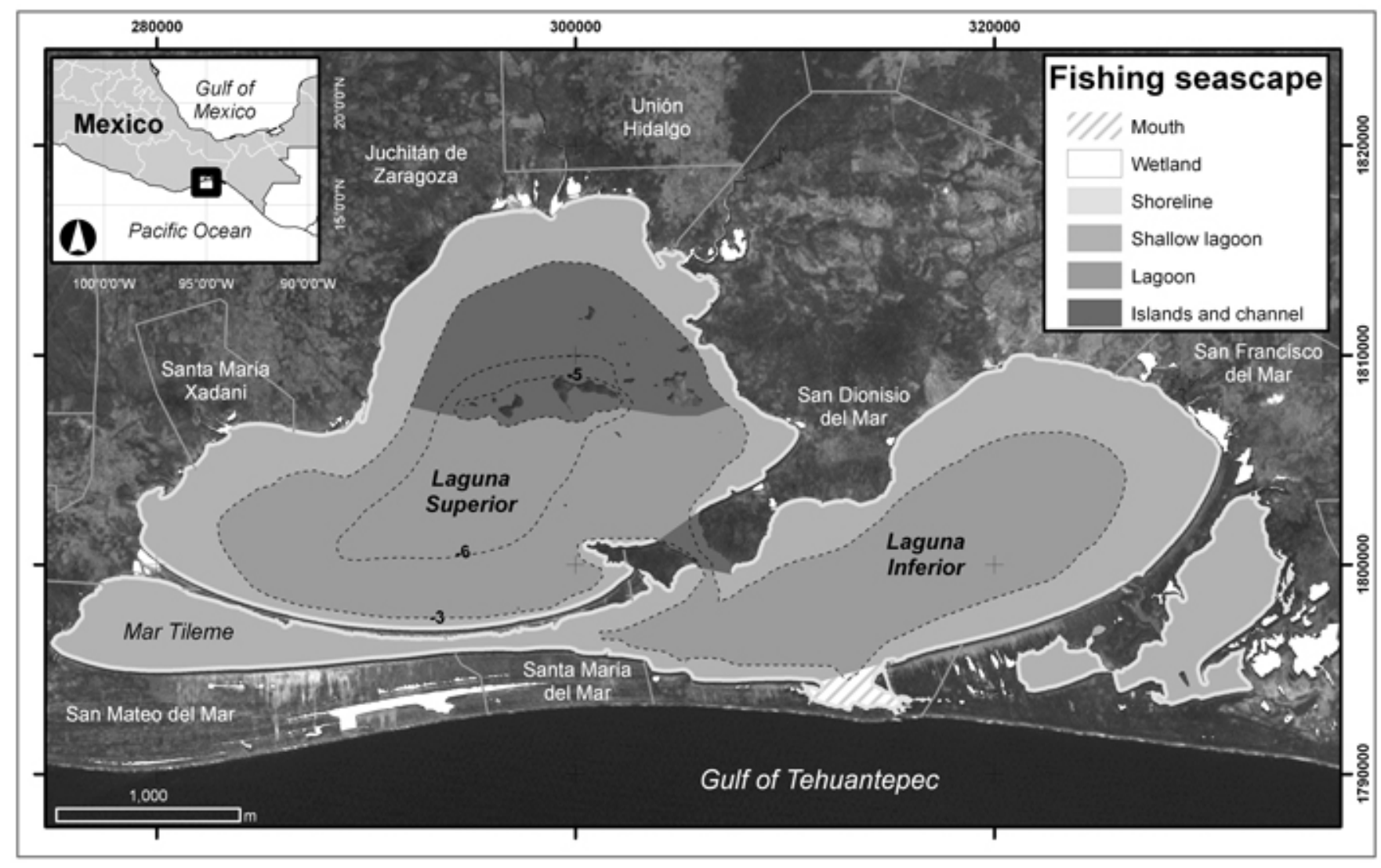

instance, decreasing the time that gillnets are left in the water can increase nontarget species' survival because they can be returned to the lagoon before they die. If this management strategy succeeds and bycatch is reduced, carnivorous species will have the potential to increase. This disturbance represented the positive input that was used to generate model predictions (Fig. 2e).

\section{RESULTS}

The TEK on the HLS is profuse because of the strong cultural attachment that people have to the area and its natural resources. The interviewed fishermen were adult men from 35 to 83 years old, living in the Zapotec and Huave fishing ports, dedicated full-time to local fisheries, and have been fishing in the HLS since childhood. All have more than 10 years of practice, and some even reach 45 and 71 years of practice (Table 1). Local fishermen have updated with fiberglass boats and small engines (15-60 hp), but wooden boats driven by rustic oars or the traditional wind propulsion system are still common in the area, as well as fishermen using the kite fishing system. They commonly earn between 8 and 15 USD per day, up to 46 USD on exceptional days. The large group of users of the lagoon resources and their readiness to collaborate in interviews and workshops are also proof of the elevated social interest on the management of the HLS.

TEK analysis allowed for the integration of biological and fishing variables within the context of the ecosystem (Table 3 ), and helped to integrate the entire community by depicting the interactions between the prevailing fisheries (pressure) in the area and the biological resources (state; Fig. 4). For example: (1) commercial fisheries exploit 16 species from three biological groups (carnivore fishes, omnivore fishes, and crustaceans), (2) gillnets and encircling gear exploit similar target species (carnivore fishes), but only gillnets have impact on sea turtles and carnivore bycatch; in contrast, shrimp nets target mainly crustaceans and primarily affect omnivore bycatch, and (3) local fisheries targets mainly carnivore species: 8 as objective resources and 24 as bycatch.

Figure 5 shows the six fishing seascapes obtained from the spatial analysis of harvested resources: mouth, wetlands, 
Table 4. Model predictions that show the response of the entire community when the management strategy oriented to reduce carnivore bycatch (CBC) is reinforced. Parentheses indicate the proportion of models from the same seascape that suggest the specified response. Example (in bold): Omnivore Bycatch $\downarrow^{(2 / 3)}-\downarrow^{(1 / 3)}=$ Two out of three positive predictions were significant and one out of three were not significant $(*)$. NA = Scenarios where this indicator is not present in the system. $\uparrow=$ Positive prediction (suggesting an increase in the group abundance); $\downarrow=$ Negative prediction (suggesting a decrease in the group abundance); $0=$ No change.

\begin{tabular}{|c|c|c|c|c|c|c|}
\hline Fishing seascape & Mouth & Wetland & Shoreline & $\begin{array}{c}\text { Shallow } \\
\text { lagoon }\end{array}$ & Lagoon & Islands/ channel \\
\hline Indicators & \multicolumn{6}{|c|}{ Biological resources predictions } \\
\hline Crustaceans $(\mathrm{Cr})$ & $\downarrow^{(3 / 3)}$ & $\downarrow^{(2 / 2)}$ & $\downarrow(3 / 3)$ & $\downarrow^{(2 / 2)}$ & NA & NA \\
\hline Mollusks bycatch (MBC) & $\downarrow^{(3 / 3)}$ & NA & $\downarrow^{(3 / 3)}$ & $\downarrow^{(2 / 2)}$ & $\downarrow(2 / 2)$ & $\downarrow(2 / 2)$ \\
\hline Omnivore fishes (OF) & NA & $\downarrow^{(2 / 2)}$ & $\downarrow^{(3 / 3)}$ & $\uparrow *^{(2 / 2)}$ & $0^{(2 / 2)}$ & $\downarrow^{(2 / 2)}$ \\
\hline Omnivore bycatch (OBC) & NA & $\downarrow^{(1 / 2)}-\downarrow^{(1 / 2)}$ & $\downarrow^{(2 / 3)}-\downarrow *^{(1 / 3)}$ & $\downarrow^{(2 / 2)}$ & $\downarrow^{(2 / 2)}$ & NA \\
\hline Carnivore fishes $(\mathrm{CF})$ & $\uparrow *^{(1 / 3)}-0^{(2 / 3)}$ & NA & NA & $\downarrow *(2 / 2)$ & $0^{(2 / 2)}$ & $\uparrow^{(2 / 2)}$ \\
\hline \multirow[t]{2}{*}{ Sea turtle bycatch (ST) } & $\downarrow^{(3 / 3)}$ & NA & NA & NA & $\downarrow^{(2 / 2)}$ & NA \\
\hline & \multicolumn{6}{|c|}{ Fishing gears predictions } \\
\hline Shrimp net (SN) & $\downarrow^{(1 / 1)}$ & $\downarrow^{(1 / 1)}$ & $\downarrow^{(1 / 1)}$ & NA & NA & NA \\
\hline Gillnets (GN) & $0^{(1 / 1)}$ & $\downarrow^{(1 / 1)}$ & $\downarrow^{(1 / 1)}$ & $0^{(1 / 1)}$ & $0^{(1 / 1)}$ & $0^{(1 / 1)}$ \\
\hline Encircling gillnet (EG) & NA & NA & NA & NA & $0^{(1 / 1)}$ & $\uparrow(1 / 1)$ \\
\hline
\end{tabular}

shoreline (depth $<1 \mathrm{~m}$ ), shallow lagoon (depth $1 \geq 3 \mathrm{~m}$ ), lagoon (depth $3>6 \mathrm{~m}$ ), and islands and channel (depth $>6 \mathrm{~m}$ ). Temporal variations within seascapes generated 14 alternative models (Fig. 6) that represent the combination of biological resources present in each seascape and the seasonal dynamics of fishing activities in the HLS. Similarities and differences between seascapes were (1) the presence of carnivore bycatch in all seascapes; (2) the absence of crustaceans in the lagoon, islands, and the channel; (3) the presence of sea turtles in the lagoon and mouth only; (4) the absence of mollusk bycatch in wetlands; and (5) the ecological role of target carnivore fishes as top predators in most of the seascapes, except in wetlands and on the shoreline where carnivore bycatch (CBC) species were the main predators.

\section{Model predictions}

Predictions obtained for the alternative models (Table 4) suggested that the response of the community to an increase in carnivore bycatch species differed between fishing seascapes for certain biological indicators such as omnivore and carnivore fishes ( $\mathrm{OF}$ and $\mathrm{CF}$ ) as well as for the gillnet fishery (GN). The response of other resources, like crustaceans $(\mathrm{Cr})$ and mollusks bycatch (MBC), was similar in all seascapes, and showed that an increase in carnivore bycatch species may not be beneficial for these two groups because all models suggested that they will decrease. Indirect effects were also evident because the decrease in mollusks bycatch (MBC) also triggered a decrease in sea turtles (ST) that depend on this prey. On the contrary, an increase in carnivore bycatch species might be beneficial for omnivore fishes (OF) that will increase in the shallow lagoon seascape and remain unchanged in the lagoon seascape. Carnivore fishes $(\mathrm{CF})$ may also increase in the mouth and islands channel, and remain the same in the lagoon seascape (Table 4). The different responses of each seascape to the analyzed disturbances were mainly due to the structure of the particular community that represented each seascape. For example, a successful increase in the abundance of carnivore bycatch species that correspond to the middle trophic level (CBC) in the mouth of the lagoon (Fig. 6; model 1 ), caused a decrease in crustaceans because of direct predation. The decrease in crustaceans reduced food availability for the group of target carnivore fishes $(\mathrm{CF})$; however, they (CF) received more food because of the increment in the populations of carnivore bycatch (CBC). Because of this indirect food web effect, the population size of top predatory fishes did not change (predictions $=0$ ). A similar response in top carnivore fishes was observed for the lagoon seascape during the fishes' season (Fig. 6; model 11).

The exclusive positive response of top carnivore fishes in the island and channel seascapes was due to the absence of crustacean $(\mathrm{Cr})$ and omnivore bycatch $(\mathrm{OBC})$ from this area in all models (13 and 14; Fig. 6). In this seascape, the increase in carnivore species that occupy a middle trophic level did not cause a decrease in the prey of top carnivores because both carnivore groups (CBC and CF) did not prey on the same items in the island and channel seascapes. For this reason, the increase of middle-level carnivores caused a direct positive effect (major food source) on the predators, the top carnivorous fishes.

The response of the alternative models that represented different fishing seasons (shrimp, low fishing season, and fishes) during the year did not show differences in their response (Table 4). For example, all three models (3/3) from shoreline seascape suggested a decrease in crustaceans $(\mathrm{Cr})$, Mollusks bycatch (MBC), Omnivore fishes (OF), and Omnivore bycatch (OBC). All the results showed this 
Fig. 6. Alternative models generated for the Huave Lagoon System, Mexico. The combination of fishing seascapes, and fishing seasons, yielded 14 alternative models. Example: Model "Mouth: 1. Fishes" represents the first model from fishing seascape "mouth," where carnivore fishes are harvested. Temporal fishing seasons are denoted by their names, model "fishes" represents the harvest that takes place from March to April and from August to December.
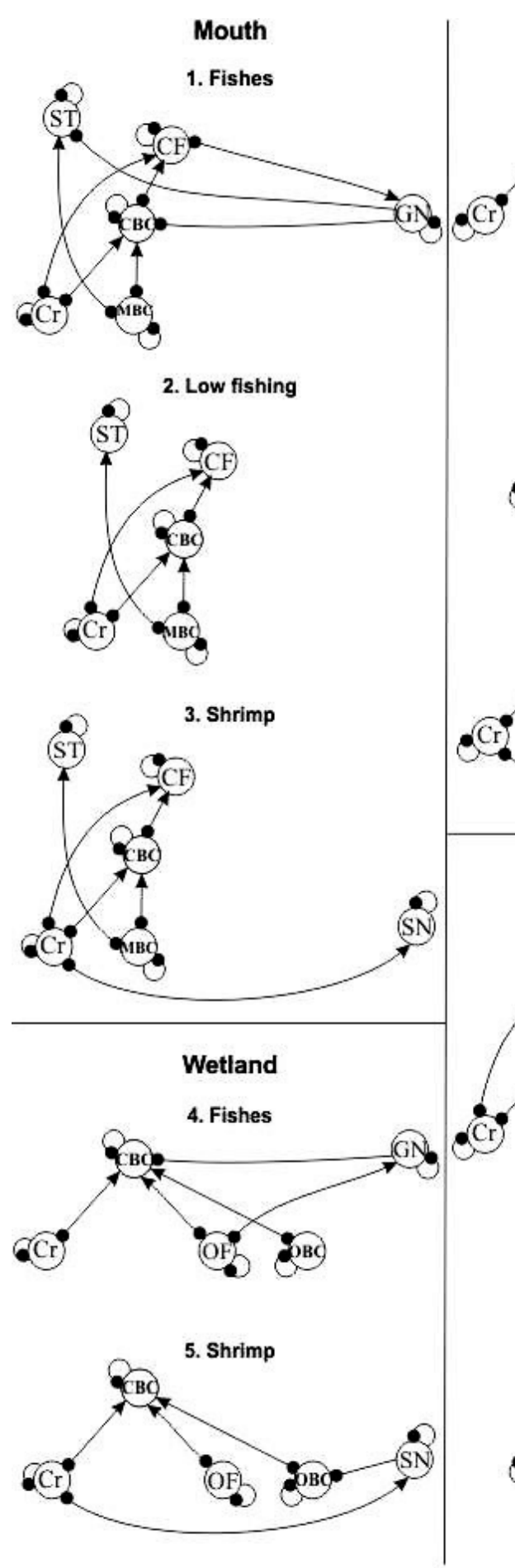
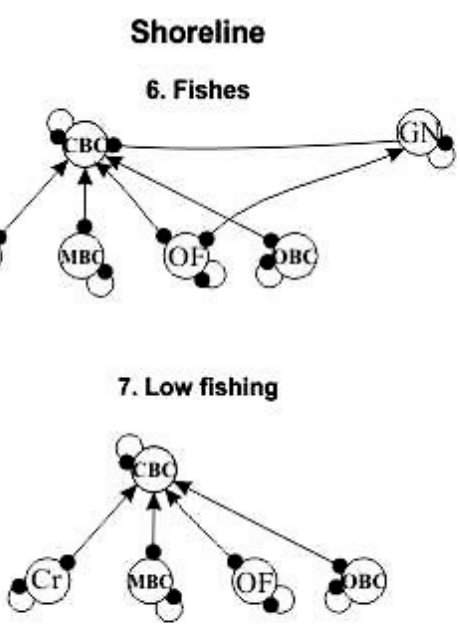

8. Shrimp
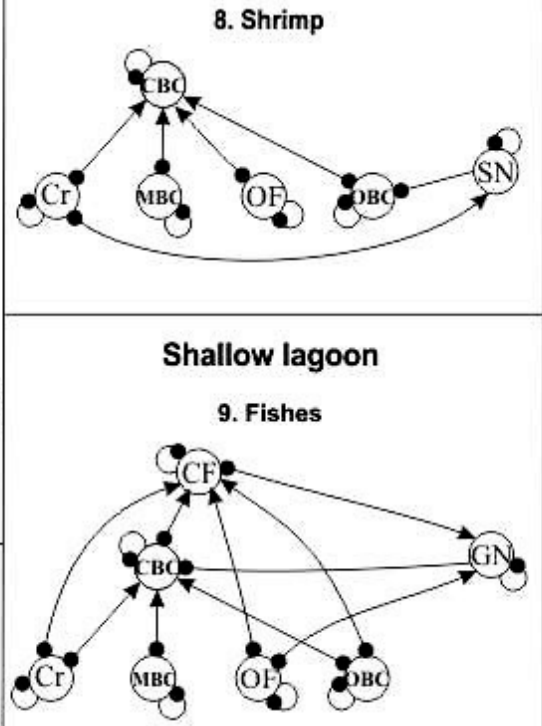

10. Low fishing

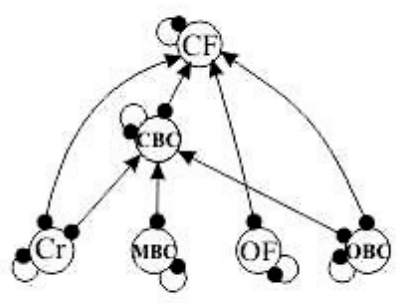

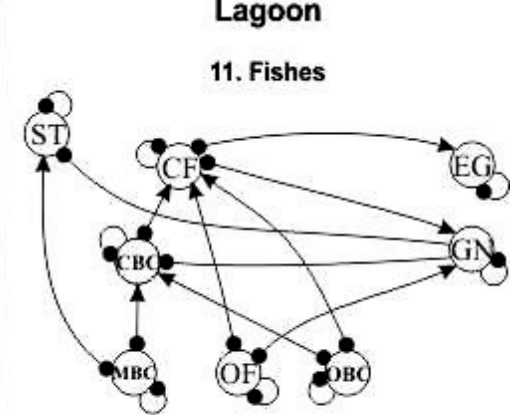

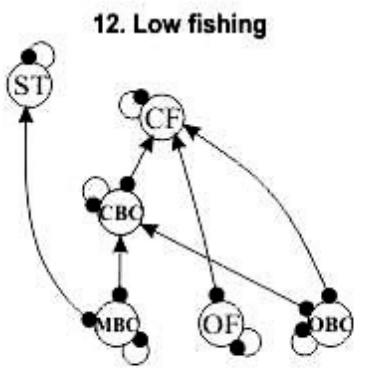

Islands and channel

13. Fishes

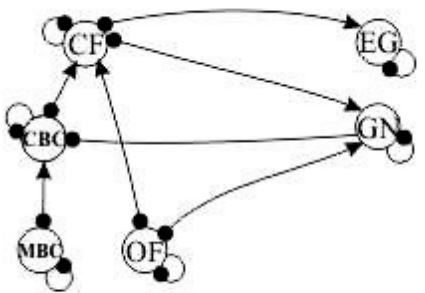

14. Low fishing

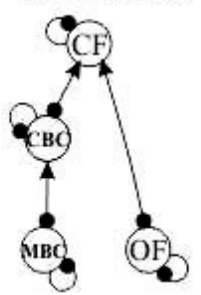

Biological indicators

$\mathrm{CBC}=$ Camivore $\mathrm{By}-\mathrm{Catch} \quad$ Fishing indicators $\mathrm{CF}=$ Carnivore Fishes

$\mathrm{CF}=$ Crustaceans
$\mathrm{MBC}=$ Mollusks By-Catch

$\mathrm{MBC}=$ Mollusks $\mathrm{By}-$ Catch
$\mathrm{OBC}=$ Omnivore By-Catch

$\mathrm{OBC}=$ Omivore $\mathrm{By}-\mathrm{C}$ OF $=$ Omnivote
ST $=$ Sea Turtle 
tendency except Carnivore fishes $(\mathrm{CF})$ from the mouth seascape.

Fishing gear predictions depended on the response of target resources to the increase of carnivore bycatch species because objective species may become more, less, or equally available for all fishing gear (Table 4). For example, shrimp net (SN) predictions suggested that catches may decrease in three seascapes (mouth, wetland, and shoreline) because the main target resource (shrimp) for this fishery may also decrease. Predictions for the encircling gillnets (EG) suggested that catches may increase in islands and channel seascapes and may remain the same in the lagoon seascape. These responses comply with the response in carnivore fishes (CF), which are the main target for this fishery. Gillnet fishery catches (GN) may decrease in the wetlands and shoreline seascapes; however, catches may remain the same in the rest of the seascapes. These results suggest that a successful bycatch reduction will be beneficial for the encircling gillnet and the gillnet fishery in specific seascapes. Predictions show that gillnet will remain the same under two fishing scenarios: (1) when gillnets affect carnivore fishes only (Fig. 6; Model 1), and (2) when gillnets harvest carnivore and omnivore fishes simultaneously (Fig. 6; Models 9, 11, and 13). On the contrary, if gillnet targets omnivore fishes only, the fishery will decrease (Fig. 6; models 5 and 6).

\section{DISCUSSION}

The HLS is situated within a Mexican coastal region (the Central and South Pacific) with a reduced capacity to generate scientific information; however, people that inhabit this territory have a deep traditional understanding of the ecosystem. Considering this complex context, we explored a transdisciplinary modeling approach (Espinoza-Tenorio et al. 2010) suitable for the area and useful for analyzing the implications of management policies considering an ecosystem-based approach. In accordance, the application of the approach in the HLS addressed some of the scientific challenges identified by Garcia and Cochrane (2005) to successfully achieve holistic fisheries management: (a) address intersectorial issues in a multidisciplinary manner; (b) deal efficiently with data-poor situations; (c) broaden the scope of information used to include fishers' knowledge, assessing their relevance and reliability and resolving apparently conflicting signals; and (d) provide ex-ante assessments as a basis for selecting an appropriate policy option.

In a multicultural region such as the HLS, it is necessary to consider the historic and current experiences and interests of the local people to greatly reduce local conflicts (Schafer and Reis 2008). In this way, the decision making process should be decentralized to the lowest level. Because of this decentralization, the consensus-building process described in this paper received the support of users of the HLS. This social involvement proved to be highly valuable for the construction of the models and, through users' participation, convenient consensual management goals were attained and tested using model predictions. During this study, the model-building process acted as an information hub where Huave and Zapotec group members could express their ecological knowledge about the HLS. Just as Espinoza-Tenorio et al. (2010) suggested, the users' involvement in the construction of fisheries management alternatives proved to be a key tool to promote ecosystem-based fisheries management strategies.

The four core analytical methods (TEK, PSR framework, loop analysis, and GIS) incorporated into the transdisciplinary model had a specific role. TEK has been suggested as a holistic management tool (Berkes et al. 2000), but practical approaches have rarely been implemented because of a general underestimation of the relevance of this kind of information. As a consequence, less attention has been paid to the importance of identifying specific areas where some management strategies might be useful and areas where they could be problematic (Rist et al. 2010). Thus, as Davis and Ruddle (2010) argue, it is necessary to exercise rational skepticism throughout the research on empirical ecological knowledge. For instance, some studies have demonstrated that fishers' local experiences may not characterize accurately such ecosystem process as predator-prey dynamics or seasonality (Davis and Wagner 2003, Ruddle and Davis 2011). However, the great value of TEK is a complement to scientific information at the local scales (Murray et al. 2008, Nenadovic et al. 2012), especially in countries where precise scientific data is unavailable or nonexistent. In the HLS, TEK might be used as hypotheses to be scientifically tested in future research. However, in the meantime, including TEK in this HLS approach contributes to a better understanding of local ecological (species feeding habits and distribution) and fisheries (fishing seasons and areas) dynamics, thus allowing for the integration of social and biological data. TEK was useful in filling database gaps and as an information source for the modeling process, as well as in critically identifying unreliable and biased information. On the other hand, the fishers ecological knowledge has different levels of detail (Neis et al. 1999) and, in the HLS, TEK was not useful on topics for which fishermen did not have extensive experience, e.g., feeding habits of nontarget species, and their information had to be corroborated by local scientists. TEK currently provides a large amount of research questions to local university students and researchers, but future conservancy efforts may eventually take advantage of TEK studies, for example, fish population dynamics and assessing reproduction and nursery areas (Schafer and Reis 2008).

The PSR framework was useful for integrating the social and biological data of the HLS and for analyzing the study variables as indicators of human activities and natural resources using data from a heterogeneous database. The 
indicators used in our research would be a first list of the minimal indicators required to obtain a holistic fisheries management "dashboard" (Garcia and Cochrane 2005) to the HLS. The PSR framework also provided a simplified multiplecause and multiple-effect systems approach that was especially useful to conceptualize the model in an environmental policy framework. This framework includes problem perception, policy formulation, monitoring and policy evaluation, which are societal responses that can only be expressed in qualitative terms (OECD 1993). Therefore, these responses could not be used by the model as indicators, but only as positive disturbances. The analysis of a management strategy aimed at reducing bycatch mortality of the most numerous group of fishes allowed us to obtain an overview of the potential situation (the state) in the HLS, regardless of whether this particular society's effort was successfully enforced. Other potential scenarios might be explored by the same model, for instance, fish exclusion techniques oriented to protect keystone species or spatial management strategies to distribute the fishing effort.

The use of loop analysis provided a better understanding of the ecosystem response when management strategies that were oriented to reduce gillnet carnivore bycatch were reinforced in the HLS. Ecological theory postulates that an increase in predators will cause a decrease in their prey populations; however, if the trophic web is highly connected, this trend is not necessarily evident because of indirect effects from other members of the community (Puccia and Levins 1985). The model predictions confirm these findings and emphasize the importance of understanding the causes of these counterintuitive changes in the ecosystem. Because qualitative modeling cannot incorporate temporal variations within one model, the use of alternative models has proven useful to analyze temporal variations in a system (Puccia and Levins 1985, Espinoza-Tenorio, et al. 2010b). Although different alternative models were proposed to represent the temporal variation of each system's seascape, all predictions were the same, suggesting that the different fishing seasons (shrimp, low fishing season, and fishes) that take place during the year are not affecting the response of the system to this particular management strategy (bycatch reduction). In addition, discrepancies among alternative models can be useful to guide monitoring efforts; for instance, the different response of carnivore fishes (CF) suggested among models indicates that it would be important to follow these group responses through time to discern if they increase or remain the same, as models have suggested (Table $4: \uparrow^{*(1 / 3)}-0^{(2 / 3)}$ ).

Insights from the modeling approach suggest that strategies such as bycatch reduction within the gillnet fishery would indeed be beneficial for this fishery if specific resources in particular areas within the HLS are harvested. For instance, to achieve this benefit the gillnet fishery can target only carnivore fishes specifically in the mouth seascape. Another option could be the simultaneous exploitation of carnivore and omnivore fishes in three seascapes (shallow lagoon, lagoon, islands and channel). Some restrictions may also apply in some areas such as the prevention of harvesting omnivore fishes alone in wetland and shoreline seascapes. These findings support the idea that harvesting different trophic levels might create a balance in the ecosystem (Pikitch et al. 2004). Although this exercise explores the consequences of one management strategy, it is useful to visualize the application of qualitative modeling to generate hypotheses related to the ecosystem based management concept. The integration of loop analysis with GIS allowed us to spatially differentiate the ecosystem or community structure that represented each area within the HLS, and detect which harvest scenarios might be in agreement with management policies aimed at protecting the ecosystem. The consensus-building process followed by this research is especially important to improve the fisheries comanagement of the area because former spatial assignment of use rights (e.g., Fishery Management Plan of the HLS; Serrano-Guzmán et al. 2007) has proven inadequate because the process does not consider the cultural diversity of the resource users or different ethnic management practices.

According to the results of the study, highly complex seascapes such as wetlands, shorelines, and shallow lagoons are key to the management of the HLS. Therefore, strategies used to organize fisheries into these seascapes should be reinforced. The classical objectives of "no take zones" do not work in local ecosystems such as the HLS, which have been subjected to more than seven centuries of collective exploitation and that support the basic and immediate needs of hundreds of users (Alcalá 1999). This fact is especially true in wetland and shoreline seascapes in the Zapotec area, on which mostly unregistered fishermen work, and which also support many fisheries year round because of their easy access and abundant resources (Table 1). The shallow lagoon is also a complex ecosystem, but compared to the more accessible seascapes, access is possible only by boat during main fishing seasons (March to April and August to September). Consequently, the three seascapes can be part of a balanced strategy that regulates fishing activities in wetlands and shoreline seascapes $(11.3 \%$ of the total area) and promotes special conservation strategies in the shallow lagoon seascapes (39.3\% of the total area). For example, because the gillnet has the largest negative effect on the ecosystem (several negative interactions caused by incidental harvest; Table 3), the use of more benign fishing gear should be encouraged in shallow lagoon areas.

\section{CONCLUSION}

A transdisciplinary method for designing a new holistic approach tailored to Mexico's fisheries context was explored in this study. This approach was useful in analyzing the implications of comanagement policies within a complex lagoon ecosystem. The counterintuitive results of this study 
highlight the importance of understanding how the ecosystem will respond to disturbances and the effect of indirect pathways on the abundance of ecosystem constituents. Although the model constitutes a qualitative approach to management, it is the first model in the area to consider the whole ecosystem, identifying key aspects on which quantitative data should be generated, e.g., type of interaction species, feeding habits of nontarget species, geo-referred ecological data. Subsequent quantitative approaches may also verify other unknown interactions that are important in reducing fishing impacts within the HLS.

The approach suggests that if the involvement of the community is a main goal of the HLS, specific management strategies should be considered for each fishing seascape that takes into account the differences between ecological structures and fishery dynamics. The analysis of seascapes can be useful for spatial management and can provide managers and users with alternative scenarios to identify the exact sources of pressure for each location, leading to focused and efficient comanagement strategies that effectively reduce the human impact on lagoon systems. Furthermore, the results show that involving users in the model-building process contributes valuable information to the process of proposing comanagement alternatives that may reduce the conflicts between local fishermen. Integrating the perspectives and opinions of the fishermen could be a key process in a consensual fishery administration and may represent an important step toward the future conservation of the HLS.

Responses to this article can be read online at: http://www.ecologyandsociety.org/issues/responses. $\mathrm{php} / 5369$

\section{Acknowledgments:}

This study was funded by Deutscher Akademischer Austausch Dienst (DAAD) under a PhD's scholarship to A.E-T and by two research projects with The Rufford Small Grants Foundation and The Inter-American Biodiversity Information Network; English editions were funded by Red de Manejo Costero, PROMEP. We thank three anonymous reviewers for all suggestions and helpful comments.

\section{LITERATURE CITED}

Alcalá, M. G. 1999. Con el agua hasta los aparejos. Pescadores y pesquerías en el Soconusco, Chiapas, México. El Colegio de Michoacán, Zamora, Mexico.

Arreguin-Sánchez, F., and E. Arcos-Huitrón. 2011. La pesca en México: estado de la explotación y uso de los ecosistemas. Hidrobiológica 21:431-462.
Bailey, C., and S. Jentoft. 1990. Hard choices in fisheries development. Marine Policy 14:333-344. http://dx.doi. org/10.1016/0308-597X(90)90055-V

Basurto, X. 2005. How locally designed access and use controls can prevent the tragedy of the commons in a Mexican small-scale fishing community. Society \& Natural Resources 18:643-659. http://dx.doi.org/10.1080/08941920590959631

Beddington, J. R., D. J. Agnew, and C. W. Clark. 2007. Current problems in the management of marine fisheries. Science 316:1713-1716 http://dx.doi.org/10.1126/science.1137362

Berkes, F., J. Colding, and C. Folke. 2000. Rediscovery of traditional ecological knowledge as adaptive management. Ecological Applications 10:1251-1262. http://dx.doi. org/10.1890/1051-0761(2000)010[1251:ROTEKA]2.0.CO;2

Berkes, F., J. Colding, and C. Folke. 2003. Navigating socialecological systems: building resilience for complexity and change. Cambridge University Press, Cambridge, UK. http:// dx.doi.org/10.1017/CBO9780511541957

Berkes, F., R. Mahon, P. McConney, R. Pollnac, and R. Pomeroy. 2001. Managing small-scale fisheries. International Development Research Centre, Otawa, Ontario, Canada.

Botsford, L. W., J. C. Castilla, and C. H. Peterson. 1997. The management of fisheries and marine ecosystems. Science 277:509-515. http://dx.doi.org/10.1126/science.277.5325.509

Bozada-Robles, L. M. 2008. Las pesquerías del complejo lagunar del Istmo de Tehuantepec, Istmo Mexicano. Dissertation. Instituto Tecnológico de Oaxaca, Oaxaca de Juárez, Oaxaca, Mexico.

Brockmann, A. 2004. La pesca indígena en México. Universidad Nacional Autónoma de México, Distrito Federal, Mexico.

Christensen, V., and D. Pauly. 1995. Fish production, catches and the carrying capacity of the world oceans. ICLARM Quaterly 18:34-40.

Christie, P., D. L. Fluharty, A. T. White, L. Eisma-Osorio, and W. Jatulan. 2007. Assessing the feasibility of ecosystem-based fisheries management in tropical contexts. Marine Policy 3:239-250. http://dx.doi.org/10.1016/j.marpol.2006.08.001

Cundill, G. N. R., C. Fabricius, and N. Marti. 2005. Foghorns to the future: using knowledge and transdisciplinarity to navigate complex systems. Ecology and Society 10(2): 8. [online] URL: http://www.ecologyandsociety.org/vol10/iss2/ $\underline{\operatorname{art} 8 /}$

Dambacher, J. M., H. W. Li, and P. A. Rossignol. 2002. Relevance of community structure in assessing indeterminacy of ecological predictions. Ecology 83:1372-1385. http://dx. doi.org/10.1890/0012-9658(2002)083[1372:ROCSIA]2.0.CO;2 
Davis, A., and K. Ruddle. 2010. Constructing confidence: rational skepticism and systematic enquiry in local ecological knowledge research. Ecological Applications 20(3):880-894. http://dx.doi.org/10.1890/09-0422.1

Davis, A., and J. R. Wagner. 2003. Who knows? On the importance of identifying "experts" when researching local ecological knowledge. Human Ecology 31(3):463-489. http:// dx.doi.org/10.1023/A:1025075923297

DOF-Federal Gazette. 2007. Ley de pesca y acuacultura sustentables. Secretería de Agricultura, Ganadería, Desarrollo Rural, Pesca y Alimentación (SAGARPA), Distrito Federal, Mexico.

Espinoza-Tenorio, A. 2010. Necesidad, conocimiento y creatividad: la pesca con papalote en Santa María del Mar, Oaxaca. Ciencia y Mar XIII:47-50.

Espinoza-Tenorio, A., L. C Bravo-Peña, J. S. SerranoGuzmán, J. A. Ronsón-Paulín, M. A. Ahumada, P. CervantesHernández, E. Robles-Zavala, M. P. Fuentes, and M. I. Gallardo-Berúmen. 2011b. La diversidad étnica como factor de planeación pesquera artesanal: Chontales, Huaves y Zapotecas del Istmo de Tehuantepec, Oaxaca, México. Pages 167-216 in G. Alcalá, and A. Camargo, editors. Estudios etnográficos sobre pesca y pescadores en América Latina y el Caribe. IPN, GEACES, México.

Espinoza-Tenorio, A., I. Espejel, M. Wolf, and J. A. ZepedaDomínguez. 2011a. Contextual factors influencing sustainable fisheries in Mexico. Marine Policy 35:343-350. http://dx.doi.org/10.1016/j.marpol.2010.10.014

Espinoza-Tenorio, A., G. Montaño-Moctezuma, and I. Espejel. 2010. Ecosystem-based analysis of a marine protected area where fisheries and protected species coexist. Environmental Management 45:739-750. http://dx.doi. org/10.1007/s00267-010-9451-0

Froese, R., and D. Pauly. 2011. FishBase. World Wide Web electronic publication. Version (10/2011). FishBase, Kiel, Germany. [online] URL: www.fishbase.org

Garcia, S. M., and K. L. Cochrane. 2005. Ecosystem approach to fisheries: a review of implementation guidelines. ICES Journal of Marine Science 62:311-318. http://dx.doi. org/10.1016/j.icesjms.2004.12.003

Gunderson, L. H., and C. S. Holling. 2002. Panarchy: understanding transformations in human and natural systems. Island Press, Washington, D.C., USA.

Hunsaker, C. T., and R. M. Hughes. 2002. Effects of landscape change on the physical and chemical components of aquatic ecosystems. Pages 286-308 in K. J. Gutzwiller, editor. Applying landscape ecology in biological conservation. Springer, New York, New York, USA. http://dx.doi. org/10.1007/978-1-4613-0059-5 16
Instituto Nacional de Estadística y Geografía (INEGI). 2005. Conteo de Población y Vivienda 2005. Dirección del Sistema Nacional de Información Municipal, Aguascalientes, México.

Islam, M. S., and M. Tanaka. 2004. Impacts of pollution on coastal and marine ecosystems including coastal and marine fisheries and approach for management: a review and synthesis. Marine Pollution Bulletin 48:624-649. http://dx. doi.org/10.1016/j.marpolbul.2003.12.004

Justus, J. 2006. Loop analysis and qualitative modeling: limitations and merits. Biology and Philosophy 21:647-666. http://dx.doi.org/10.1007/s10539-006-9050-x

Levins, R. 1974. The qualitative analysis of partially specified systems. Annals of the New York Academy of Sciences 231:123-138. http://dx.doi.org/10.1111/j.1749-6632.1974.tb20562. $\underline{x}$

Loiselle, S., G. M. Carpaneto, V. Hull, T. Waller, and C. Rossi. 2000. Feedback analysis in reserve management: studying local myths using qualitative models. Ecological Modeling 129:25-37. http://dx.doi.org/10.1016/S0304-3800(00)00217-9

Ludwig, D., R. Hilborn, and C. Walters. 1993. Uncertainty, resource exploitation, and conservation: lessons from history. Science 260:17-36. http://dx.doi.org/10.1126/science.260.5104.17

Millán. S. 2003. Huaves. CDI, Distrito Federal, México.

Montaño-Moctezuma, G., H. W. Li, and H. W. Rossignol. 2007. Alternative community structures in a kelp-urchin community: a qualitative modeling approach. Ecological Modeling 205:343-354. http://dx.doi.org/10.1016/j.

ecolmodel.2007.02.031

Morse, W. C., M. Nielsen-Pincus, J. Force, and J. Wulfhorst. 2007. Bridges and barriers to developing and conducting interdisciplinary graduate-student team research. Ecology and Society 12(2): 8. [online] URL: http://www.ecologyandsociety. org/vol12/iss $2 /$ art8/

Munro, J. L. 2011. Assessment of exploited stocks of tropical fishes: an overview. Pages 145-170 in V. Christensen and J. Maclean, editors. Ecosystem approaches to fisheries. Cambridge University Press, New York, New York, USA. http://dx.doi.org/10.1017/CBO9780511920943.012

Murray, G., B. Neis, C. T. Palmer, and D. C. Schneider. 2008. Mapping cod: Fisheries science, fish harvesters' ecological knowledge and cod migration in the northern Gulf of St. Lawrence. Human Ecology 36:581-598. http://dx.doi. org/10.1007/s10745-008-9178-1

Nauen, E. C. 2002. How can collaborative research be more useful to fisheries management in developing countries? Pages 357-364 in J. M. McGlade, P. Cury, K. A. Koranteng, and N. J. Hardman-Mountford, editors. The Gulf of Guinea large 
marine ecosystem. Elsevier Science, Amsterdam, the Netherlands.

Neis, B., D. C. Schneider, L. Felt, R. L. Haedrich, J. Fischer, and J. A. Hutchings. 1999. Fisheries assessment: what can be learned from interviewing resource users. Canadian Journal of Fisheries and Aquatic Sciences 56:1949-1963.

Nenadovic, M., T. Johnson, and J. Wilson. 2012. Implementing the Western Gulf of Maine Area Closure: the role and perception of fishers' ecological knowledge. Ecology and Society 17(1): 20. http://dx.doi.org/10.5751/ES-04431-170120

Organization for Economic Co-Operation and Development (OECD). 1993. OECD core set of indicators for environmental performance reviews. Environment monographs 83, OECD, Paris, France.

Organization for Economic Co-Operation and Development (OECD). 2005. Agricultural and fisheries policies in Mexico, recent achievements, continuing the reform agenda. OECD, Paris, France.

Ortiz, M., and M. Wolff. 2002. Application of loop analysis to benthic systems in northern Chile for the elaboration of sustainable management strategies. Marine Ecology Progress Series 242:15-27. http://dx.doi.org/10.3354/meps242015

Ortiz-Lozano, L., A. Granados-Barba, V. Solís-Weiss, and M. A. García-Salgado. 2005. Environmental evaluation and development problems of the Mexican Coastal Zone. Ocean \& Coastal Management 48:161-176. http://dx.doi.org/10.1016/ j.ocecoaman.2005.03.001

Ostrom, E. 2009. A general framework for analyzing sustainability of social-ecological ecosystems. Science 325:419-422. http://dx.doi.org/10.1126/science.1172133

Pikitch, E. K., C. Santora, E. A. Babcock, A. Bakun, R. Bonfil, D. O. Conover, P. Dayton, D. Doukakis, D. Fluharty, B. Heneman, E. D. Houde, J. Link, P. A. Livingston, M. Mantel, M. K. McAllister, J. Pope, and K. J. Sainsbury. 2004. Ecosystem-based fishery management. Science 305:346-347. http://dx.doi.org/10.1126/science.1098222

Puccia, J. C., and R. Levins. 1985. Qualitative modeling of complex systems: an introduction to loop analysis and time averaging. Harvard University Press, Cambridge, Massachusetts, USA.

Rist, L., R. Uma Shaanker, E. J. Milner-Gulland, and J. Ghazoul. 2010. The use of traditional ecological knowledge in forest management: an example from India. Ecology and Society 15(1): 3. [online] URL: http://www.ecologyandsociety. org/vol15/iss 1/art3/

Rivera-Arriaga, E., and G. Villalobos. 2001. The coast of Mexico: approaches for its management. Ocean \& Coastal
Management 44:729-756. http://dx.doi.org/10.1016/S0964-5691 $\underline{(01) 00078-3}$

Ruddle, K., and A. Davis. 2011. What is "ecological" in local ecological knowledge? Lessons from Canada and Vietnam. Society \& Natural Resources 24(9):887-901. http://dx.doi. org/10.1080/08941921003598796

Sáenz-Arroyo, A., C. M. Roberts, J. Torre, M. Cariño-Olvera, and R. R. Enríquez-Andrade. 2005. Rapidly shifting environmental baselines among fishers of the Gulf of California. Proceedings of the Royal Society B Biological Sciences 272:1957-1962. http://dx.doi.org/10.1098/rspb.2005.3175

Schafer, A. G., and E. G. Reis. 2008. Artisanal fishing areas and traditional ecological knowledge: the case study of the artisanal fisheries of the Patos Lagoon estuary (Brazil). Marine Policy 32:283-292. http://dx.doi.org/10.1016/j.marpol.2007.06.001

Serrano-Guzmán, S. J. 2004. Estudio de ordenamiento ecológico para la zona costera del Istmo de Tehuantepec que favorezca y contribuya al desarrollo ordenado y racional de la pesca y acuacultura. Universidad del Mar, Puerto Ángel, Oaxaca, México.

Serrano-Guzmán, S. J., P. Cervantes-Hernández, E. RoblesZavala, and G. González-Medina. 2007. Plan de manejo acuícola y pesquero de la zona Huave, Oaxaca. Technical report, CONAPESCA, Subsecretaria de Pesca y AcuiculturaOaxaca y Universidad del Mar, Puerto Ángel, Oaxaca, México.

Smith, A. D. M., E. J. Fulton, A. J. Hobday, D. C. Smith, and P. Shoulder. 2007. Scientific tools to support the practical implementation of ecosystem-based fisheries management. ICES Journal of Marine Science 64:633-639. http://dx.doi. org/10.1093/icesjms/fsm041

Wilson, J. A. 2006. Matching social and ecological systems in complex ocean fisheries. Ecology and Society 11(1): 9. [online] URL: http://www.ecologyandsociety.org/vol11/iss1/ $\underline{\operatorname{art} 9 /}$ 
Appendix 1. Questionnaire used for collecting traditional ecological knowledge on the Huave Lagoon System, Mexico.

Both Spanish and English versions of the questionnaire can be found here:

http://www.ecosur.mx/ecosur/index.php/recursos-acucos-sistemastop-43/pesquerartesanales-sistemastop-66/287-investigaci/spa/2065-alejandro-espinoza-tenorio.html 